\title{
HAN, B.-C. (2016). O AROMA DO TEMPO. \\ UM ENSAIO FILOSÓFICO SOBRE A ARTE DA DEMORA. LISBOA: RELÓgIO D’ÁGUA.
}

\author{
Vítor de Sousa
}

In his essay, $O$ aroma do tempo. Um ensaio filosófico sobre a arte da demora [The scent of time. A philosophical essay on the art of delay] (2016), originally published in Germany, in 2007, Byung-Chul Han argues that contemporary life is overpowered not by the continuous acceleration of time, but rather a temporal crisis caused by a dyschronicity (a discontinuity), which is simply the atomization of time with no direction, order or end that prevents it from lasting (lingering). It consists of indistinguishable, sequential moments, which means that every instant is just like any other, lacking rhythm or direction that can add meaning to our lives.

Byung-Chul Han proposes the revitalization of the art of lingering as contemplation of the truth, which, paradoxically, is not related to any kind of alienation from reality. According to the author, this temporal crisis is the result of our inability to contemplate, since reality, because it is fleeting and instantaneous, does not allow for human beings to feel fulfilled, due to the lack of depth and the excess of an ephemeral dynamic. In reference to Zygmunt Bauman's conceptualisations of something he called "liquid modernity", he argues that everything is lived like it is ephemeral, and death is seen simply as a premature, and almost always, senseless instant. We "zap" through the world and every one of us becomes something radically fleeting, and prone to suffer from what Heidegger typified as "harassed unrest" and "non-dwelling".

This hallucination, which results from whizzing through infinitude, made the philosopher restless and think of the denarration of time and the loss of direction. It does not mean that the proclaimed end of the grand narratives (Lyotard, 1986) is valid, along with the consequent and usual ensuing apocalypse. It will only be so once we give back time its instantaneity, in which narrative time does not lead to a vegetative time.

And even though Byung-Chul Han guarantees that this temporal crisis has nothing to do with a general process of acceleration, which has shattered the so-called stable truths sculpted in modernity, the fact is that this statement underlies the philosopher's explanations. In order to make it right, he proposes the revitalization of the vita contemplativa (concept associated with authors like Nietzsche, Heidegger, Aristotle, Saint Augustine or Thomas Aquinas, who he quotes systematically in his essay, apart from other renowned authors) in detriment of a relativization of the vita activa associated with the loss of world and time. The proposal to overcome this rush is based on contemplation, certainly slower and necessarily more meditative, since the vita activa deprived the homo 
laborans from leisure time. The author dedicated a whole chapter to contemplation, addressing the revaluation of work which, in the course of modern times, leads to work's absolute status, even to its glorification, and is a very complex phenomenon. About that he argues that "the causal interrelation and reciprocity between labour, capital, power, domination and salvation are deeply entangled. The economy of salvation and the economy of power permeate each other" (p. 113). Jonathan Crary, in 24/7: Late capitalism and the ends of sleep (2013), explores some of the ruinous consequences of the expanding non-stop processes of twenty-first-century capitalism. His vision, though, clashes with Han's because it argues that human sleep is intrinsically incompatible with non-stop capitalism. He points to other more formidable and collective refusals of world-destroying patterns of growth and accumulation.

O aroma do tempo. Um ensaio filosófico sobre a arte da demora [The scent of time. A philosophical essay on the art of delay] investigates the causes and symptoms of dyschronicity in historical as well as systematic terms, but it also offers reflections on possibilities for recovery. While these touch upon heterochronic or uchronic moments, the present study, according to the author, is not limited to finding and rehabilitating these exceptional, extraordinary places of duration: "it will not mourn the passing of time of storytelling. The end of narration, the end of history, does not need to bring about a temporal emptiness. Rather, it opens up the possibility of a life-time that can do without theology and teleology, but which possesses a scent of its own, "but this presupposes a revitalization of the vita contemplativa" (p. 10). Byung-Chul Han analyses the paradox based on the idea that everything happens simultaneously and everything is possible, the present shortens and loses all duration. That is why he states that "we zap across the world" and he lets us know exactly what his intentions are in the "Preface" to his work: "today's temporal crisis is not a crisis of acceleration. The age of acceleration is already over. What we experience today as acceleration is only one of the symptoms of temporal dispersal". Today's crisis is, then, caused by a dyschronicity, which leads to various temporal disturbances or paresthesia. Time is lacking a rhythm that provides order. "Dyschronicity lets time whizz, so to speak. The feeling that life is accelerating is really the experience of a time that is whizzing without a direction" (p. 9). This means that dyschronicity is not the result of a push further acceleration, rather that the atomization of time is responsible for dyschronicity. It is also the reason for the feeling that time passes much more quickly than it used to. Due to the temporal dispersal no experience of duration is possible: "nothing comports time. Life is no longer embedded in any ordering structures or coordinates that would found duration". Thus, we become radically transient ourselves: "the atomization of life goes hand in hand with an atomization of identity. All we have is our self, our little ego" (pp. 9-10).

The author points out that poverty of world is a phenomenon of dyschronicity and reduces the human being to a tiny body that is kept healthy at all costs. Otherwise, what would we have? - he asks. "In a sense, we are subject to a radical loss of time, of being-with (Mitsein). The health of one's fragile body is a substitute for world and God. Nothing outlasts death. (...) We age, without becoming old" (p. 10). This does not mean 
contemporary life is less connected to the absolute nature of the vita activa, as it leads to an imperative work which degrades the human being into an animal laborans. "The hyperkinesia of everyday life deprives human existence of all contemplative elements and of any capacity for lingering. It leads to a loss of world and time". The so-called strategies of deceleration do not overcome this contemporary temporal crisis. What is necessary is a revitalization of the vita contemplativa: "the temporal crisis will only be overcome once the vita activa, in the midst of its crisis, again incorporates the vita contemplativa" (pp. 10-11).

Byung-Chul Han's writing is crystal clear, and sometimes assumes real "soundbite" proportion (eg. "We zap across the world", p. 56). Ideas are perceived at first reading, even if their complex nature might tell us otherwise. The scent of time is divided into 12 chapters. In "Non-time" (p. 13), the author chooses Nietzsche to open hostilities and argues that today's acceleration results from the general inability to end and to conclude: "time is running off because it cannot find an end or conclusion because it is not ruled by any gravitational structure". Acceleration means that there are no temporal sections that regulate, articulate or give rhythm to the flow of time, or that can stop it or guide it (p. 14); in "Time without a scent" (p. 25) he addresses the issue of historical time, in which there is no long-lasting present, and nothing persists in a still order. Time does not go back, rather pushes forward; does not repeat, rather catches up, leaving the past and the future unbalanced. Historical time is linear, but it manifests itself in different ways. "Human beings are no longer free. They belong to God. They do not project towards the future. They do not project their time. They are involved in the end of the world and time. They are not History's subject" (p. 27).

In the chapter entitled "The speed of history", the author mentions that new technologies push human beings away from the Earth, because "airplanes and spaceships pull them away from the Earth's gravitational field", and the further one moves from the Earth, the smaller it gets. And the faster one moves on the Earth, the more it shrinks. The internet and electronic mail let geography, even the Earth itself, disappear" (p. 33). In the next chapter, "From the age of marching to the age of whizzing" (p. 43), Han uses Zygmunt Bauman to refer to the modern human as a pilgrim who wanders the world as if it were a desert, giving form to the formless, continuity to the episodic and making what was once fragmented whole again. However, according to Han the modern pilgrim lives an "on-the-way" life, whose world is "determined"; therefore, Bauman's "pilgrim" does not match the modern human since the peregrinus feels a stranger in this world. Shrinking the present does not empty nor dilutes time, and the paradox is based on the fact that "everything happens simultaneously, everything is possible or should be now". That is how "we zap around the world" (p. 56). In the following chapters entitled "Fragrant crystal of time" (p. 57) and "The time of the angel" (p. 65) he recovers the idea of the end of the grand narratives, regarding it as "the end of an epic age characterized by narration and history - which links events into a story and, by establishing a relation, creates meaning". The end of narration is, therefore and first and foremost, "a temporal crisis", which tears apart any temporal gravitation that can link past and future into the present: 
"post-modernists tend to delineate different strategies for time and of the human being as to avert the decay of time, detemporalization" (pp. 65-66).

Other chapters included in the book are "Fragrant clock: a short excursus on ancient China" (p. 71), "The round dance of the world" (p. 77) and "The scent of oak wood" (p. 87), in which he refers to the general acceleration of life which deprives the human being from the ability to contemplate. He writes that "acceleration is not a primary process, which subsequently leads to the loss of the vita contemplativa", so the relation between acceleration and loss of vita activa is much more complex. The book ends with the chapters "Profound boredom" (p. 97) and "Vita contemplativa" (p. 103), previously mentioned, which ends like it started, with a quote by Nietzsche: "from lack of rest our civilization is ending in a new barbarism. Never have the active, that is to say the restless people, been prized more". That is why needed improvements in human beings should include "the strengthening of the vita contemplativa" (p. 135).

This means that "if one is to deprive life from rest, it will become lethally hyperactive" and one will ultimately "drown in one's own subject". The revitalization of the vita contemplativa is, therefore, necessary "because it opens up spaces for breathing (Atemraum). Perhaps the mind owes its emergence to an excess of time, an otium, even to a slowness of breath" (pp. 135-136).

Since the 1960's, we have been living in the age of Information and Communication Technologies resulting from the acceleration and change in the concept of time. The subsequent fragmentation and the integration of new realities resulted in a crisis of paradigm (Lyotard, 1986) which led to a crisis of identity (Hall, 1992). All the logic of modernity was deconstructed, causing a deviation from what was thought to be stable, questioning the legitimacy and the "kindness" of the previous explanation. Having all been summoned to the present, and knowing there is a beginning but not an end, the Hegelian dialectic of thesis, antithesis and synthesis falls apart (Martins, 2011). ByungChul Han agrees, even though he points out that the end of time with a narrative duration would not have to bring about a temporal emptiness. Instead, there is now the possibility of a life-time that does without theology and teleology but which possesses a scent of its own. One would have to bring back Hannah Arendt's concepts set out in The human condition, in which thinking was always a privilege of just a few: "but precisely because of that, the amount of those few remained the same" (p. 129), since the temporal crisis will only be overcome once the vita activa again incorporates the vita contemplativa.

The South Korean philosopher born in Seoul, in 1959, and living in Germany since the 1980's, where he studied Philosophy, Literature and Theology in the universities of Munich and Freiburg, having received his doctoral degree in 1994 with a dissertation on Heidegger, has devoted his work to the main subjects and problems of modern-day societies; to the causes for those changes, reflecting on a chance to reverse them. In The agony of Eros (2014b), he argues on the trivialization of love and fantasy concerning the emergence of narcissistic, consumerist and pornographic impulses. The burnout society (2014a) is about stress, burnout and disturbance at work and in the family home; Psychopolitics (2014C) and The transparency society (2014d) are both a critique of democracy, 
capitalism and the totalitarian power of new technologies and digital reality. In a more recent book, The expulsion of the Other (2016), Han stresses the idea that what is sick to society is not alienation, prohibition or repression, but excessive information and hyperconsumption, making it clear that globalization leads to the expulsion of the different and the disappearance of the "other", whomever it is. A temporal revolution is necessary to start a totally different time: "unlike the time of the self, which isolates and separates us, the time of the Other creates a community. It is therefore a good time" (p. 95). In Psychopolitics (2014C), the author had already referred to the "idiot", describing him not as the one with questionable behaviours, but the one who gets away to contemplate (the "modern heretic"), which, incidentally, also happens in The scent of time, making time whole and allowing the rescue of narration as a creative force. Idiotism opposes, then, "the totalitarian power of neoliberalism over communication and surveillance" (p. 89).

These are thoughts Byung-Chul Han himself often addresses, like in the interview with Carles Geli (El Pais, Brasil), when he argues that one should revitalize the use of time, since "today's acceleration diminishes one's ability for lingering". We need our own, free time, which labour prevents us from having, that means to keep quiet, with nothing to do, "but it should not be mistaken for recovering time to keep working; time worked is time lost, it is not time for ourselves" (2018, s.p.).

According to Han, who demonises work and, as an alternative, chooses contemplation, through leisure, what we need to know is if this is the way to reformulate temporal dispersal which, even if he argues it has nothing to do with the general acceleration process, has everything to do with it.

Translation: Helena Antunes

\section{REFERENCES}

Crary, J. (2013). 24/7: Late capitalism and the ends of sleep. London/New York: Verso.

Geli, C. (2018, 7 de fevereiro). Byung-Chul Han: "Hoje o indivíduo se explora e acredita que isso é realização". El Pais, Brasil. Retrieved from https://brasil.elpais.com/brasil/2018/02/07/cultura/1517989873_086219. html?\%3Fid_externo_rsoc=FB_BR_CM

Hall, S. (1992). A identidade cultural na Pós-modernidade. Rio de Janeiro: DP\&A.

Han, B.-C. (2014a). A sociedade do cansaço. Lisboa: Relógio d'Água.

Han, B.-C. (2014b). A agonia de Eros. Lisboa: Relógio d'Água.

Han, B.-C. (2014c). Psicopolítica. Lisboa: Relógio d'Água.

Han, B.-C. (2014d). A sociedade da transparência. Lisboa: Relógio d'Água.

Han, B.-C. (2016). A expulsão do Outro. Lisboa: Relógio d'Água.

Lyotard, J.-F. (1986). O Pós-moderno. Rio de Janeiro: José Olympio.

Martins, M. L. (2011). Crise no castelo da cultura - das estrelas para os ecrãs. Coimbra: Grácio Editor. 


\section{BIOGRAPHICAL NOTE}

Vítor de Sousa received his PhD degree in Communication Sciences (Intercultural Communication), from the University of Minho, with the thesis Da 'portugalidade' à lusofonia. He received his Master's degree (with specialization in Media Literacy) and graduated in the same field of expertise (specialization in Communications/Information and Journalism). His areas of research include issues around identity, cultural studies, media literacy and theories of journalism. He is a researcher at CECS (Communication and Society Research Centre), where he integrates a Cultural Studies Group. He is member of the project "Cultures Past \& Present - Memories, cultures and identities: how the past weights on the present-day intercultural relations in Mozambique and Portugal?" (FCT/Aga Khan) and of the Virtual Museum of Lusophony. He is member of Sopcom (Portuguese Association of Communication Sciences), ECREA (European Communication Research and Education Association) and of the Associação dos Amigos da Biblioteca Municipal de Penafiel (Friends of the Penafiel Public Library Association). He has won the Mário Quartin Graça Scientific Award in 2016, which distinguished the best thesis concluded in the previous three years in the area of Social Sciences and Humanities in Portugal and Latin America. He was a journalist (1986-1997) and a press officer (1997-2005).

ORCID: https://orcid.org/0000-0002-6051-0980

Email: vitordesousa@gmail.com

Address: CECS-Centro de Estudos de Comunicação e Sociedade, ICS-Instituto de Ciências Sociais, Universidade do Minho, Campus de Gualtar, 4710-057 Braga

Submitted: $18 / 01 / 2019$

Accepted: $18 / 02 / 2019$ 